\title{
Quantitative Recommendation of Phosphorus Fertilizer Based On The Correlation Between Phosphorus of Plant Organs and Soil Phosphorus In Washington Navel Oranges
}

Abdolkarim Ejraei ( $\sim$ soilira@yahoo.com)

Islamic Azad University Jahrom Branch https://orcid.org/0000-0002-1826-8553

\section{Research Article}

Keywords: Soil Phosphorus, Regression Models, Washington Navel Orange, Fertilizer Recommendation, Integrated Plant and Soil System (IPSS)

Posted Date: May 13th, 2021

DOI: https://doi.org/10.21203/rs.3.rs-512234/v1

License: (ㄷ) (1) This work is licensed under a Creative Commons Attribution 4.0 International License. Read Full License 


\section{Abstract}

Aim

Many methods have been proposed to recommend plant nutrients, all of which are qualitative and based on the concentration of the element in the soil or leaves. But, in the "Integrated Plant and Soil System" (IPSS) method, there is a recommendation of fertilizer quantified and based on the correlation between concentration of elements in plant and soil organs.

\section{Methods}

In this study, 39 Washington Navel Oranges orchards were selected and in each orchard, three trees were chosen and sampled from roots, stems, leaves, fruit as well as the soil around the roots. Sampling was performed in late March and early May for two consecutive years and phosphorus was measured in the samples. After a correlation analysis between "soil properties and phosphorus of plant organs" with soil phosphorus, those factors that had a significant correlation with soil phosphorus were selected. And based on that, there was determined a regression model between them.

\section{Results}

Among all the studied factors, fruit phosphorus had the highest correlation with soil phosphorus. Based on that, two regression equations were obtained by which the required phosphorus can be calculated.

\section{Discussions}

Since the physicochemical properties of each element are different from the other, so the leaf alone cannot be a good indicator to determine the nutritional status of all elements. Therefore, it is more logical that the fertilizer recommendation of each element is based on the correlation between the element in that organ of the plant that has the highest correlation with that element in the soil.

\section{Introduction}

Nowadays, without regard to the nutrient elements of the soil, increasing production of crops in any region of the developing world will not be possible. One of the ways to improve the status of soil nutrient elements is application of fertilizers. These compounds, in addition to increasing the production and improving the quality of agricultural products, should not cause pollution of the environment and the accumulation of contaminants in the plant organs (Lu et al. 2013; Bujnovsky et al. 2016; Su et al. 2017). Phosphorus (P) as an essential nutrition element plays an important role in the physiological and biochemical processes of plants (Vance et al. 2003; Zambrosi et al. 2013; Ceulemans et al. 2017; $\mathrm{Li}$ et al. 2020). Among the essential nutrients, $\mathrm{P}$ has the greatest impact on the development and progress of reproductive organs, and as long as the $\mathrm{P}$ deficiency is not corrected, many products do not respond to nitrogen uptake (Sanchez 2007; Ford et al. 2016; Xiao et al. 2019; Pantigoso et al. 2020). In recent decade, much attention has been paid to the role and effect of excessive applied of $\mathrm{P}$ fertilizer on soil quality, crop quantity and the environment changes in around the world (Halitligil et al. 2002; Malhi and Lemke 2007; Halajnia et al. 2009; Ma et al. 2009; Valkama et al. 2009; Ferrise et al. 2010; Liang et al. 2011). Many studies have shown that excessive fertilizer uses by farmers who tend to produce more often does not always contribute to increase yields, but excessive apply causes the waste of fertilizer and its negative effects on the environment (Ju et al. 2009). Contamination of groundwater and surface (Le et al. 2010), greenhouse gas emissions (Zheng et al. 2004), accumulation of nutrient elements (Chen et al. 2006) and nutrient leaching (Zhang et al. 2005). So increasing the use of fertilizers will cause more and more problems for the environment in the world in future. Therefore, it is necessary to find a suitable fertilizer recommendation system that can not only 
improve the nutrient requirements for more production, but also helps maintain environmental sustainability (Xu et al. 2014). So far, various methods have been proposed to determine the status of nutrients in soil and plants, including morphological symptoms, soil test and plant analysis (Sajjadi 1992; Mourao Filho 2004; Robinson 2005). Also, Data results of soil and plant analysis in order to interpret and recommend fertilizer are evaluated by different methods, such as Critical Nutrient Concentration, sufficiency Range, Cate and Nelson diagram, Deviation from optimal percentage (DOP), Diagnosis and Recommendation Integrated System (DRIS (Cate and Nelson 1965; Beufils 1973; Dow and Roberts 1982). Although DRIS and DOP methods are more common than other methods, they also have weaknesses. The DOP method is not widely used due to lack of reference numbers for most plants (Lucena 1997). This method requires the collection of a series of data such as climate, topography, soil test, plant species, etc. If the accuracy of each factor is reduced, will be affected on the norm of each element. Also, the amount of the element in the soil or plant is not quantitatively and expressed with terms such as positive and negative (Ciesielska et al. 2002; Garcia-Escudero et al. 2013). In the DRID system, unlike other methods, the interpretation of leaf analysis results does not depend on the physiological age and site of sampling and in this method, the leaf is considered to be the most important place for plant analysis (Beufils 1973; Beverly et al. 1984; Sumner 1977). Efficiency of the DRIS method is when all the nutrients in the plant are examined together, so the limitation of this method is when only one or two elements of the plant are to be examined. Another weakness is the complexity of the method, which results in errors in the interpretation of the results and the recommendation of fertilizer, as well as deficiency or excessive amount of the element in the soil or plant is not expressed quantitatively and instead of that are used terms such as low, high or sufficient. As indicated the fertilizer recommendation is often based on the concentration of the element in the soil or plant, and there is less method in which the advice is based on the concentration of the element in the plant and soil (Vasileios et al. 2013). Also, in all available methods, the leaf is considered as the main organ of the plant to study the status of all nutrients, while the method of absorption, transfer, accumulation and role of each element in each organ is different from the other element in a plant. Therefore, it does not seem logical, leaves as an organ to determine the status of all the nutritional elements. Considering the above, and given that citrus fruits are evergreen and require more water and nutrients than deciduous plants, so to recommend fertilizer, there is necessary to use a quantitative method that not only provides plant nutrients but also does not pollute the environment. IPSS method can be a good system for fertilizer management and environmental protection. For these reasons the purpose of this research; 1) Determine the organ that the phosphorus content has the highest correlation with the phosphorus content of the soil. 2) Determine the model in which the fertilization recommendation is based on the relationship between the concentration of the element in the soil and the plant organs which is termed "integrated plant and soil system"(IPSS).

\section{Material And Methods}

Study area

The study was conducted in Jahrom (N 35, 32; E 28, 29) from March 2019 to June 2020, which is one of the most important citrus cultivation areas in Iran. The climate is arid to the semi-arid, the annual rainfall does not exceed 250 $\mathrm{mm}$, and the average annual air temperature fluctuates around 21.24 centigrade. Agriculture, especially citrus and palm farming constitute the main economic activity of the local people.

\section{Sampling and experimental analysis}

In this research, 39 Washington Navel Orange (WNO) orchards were selected each from 8 to 10 hectares, and the average age of orchards in different areas of Jahrom was from 8 to 10 years. According to the previous years, yield and applied fertilizers were classified into three categories of low, medium and high yield gardens. Of these, 18 orchards were classified in a high yield group while more fertilizers were used (gardens in which 220-280 kg of ammonium sulfate and super triple phosphate, 250-300 kg potassium sulfate, and 40-70 kg Magnesium sulfate were consumed in hectare 
per year and yields of 60 to 70 -ton $\mathrm{ha}^{-1}$ ). Meantime 10 orchards were used as the moderate group (in which 100-130 kg of ammonium sulfate and super triple phosphate, $20-40 \mathrm{~kg}$ of Magnesium sulfate were consumed in hectare per year and high yield of 30 to 40 -ton ha-1 ${ }^{-1}$ ), And 11 orchards as low yields and low fertilizer consumption (with less than 80-100 $\mathrm{kg}$ of ammonium sulfate and super triple phosphate per hectare and yield of 10-20 tons per hectare in a year). In two consecutive years $(2019,2020)$, sampling was performed twice a year, the first sampling in late March and the second in the early May. Since 39 orchards were surveyed and three Washington Navel orange trees were chosen in each orchard and each tree was sampled four times in two consecutive years, thus totally 468 trees were sampled. It is very important that the two executive sample have time period correspondence (Estefan et al. 2013). Samples were taken from each side of the trees and from the roots, stems, old and young leaves, fruits and soil around the roots. Samples were packed in paper bags and transported to the laboratory (Carter 1993). Plant specimens were disinfected in 5\% sodium hypochlorite, washed with distilled water and exposed to air to be dried (Campbell and Plank 1998; Jones 1998).

Samples were Oven dried at $60^{\circ} \mathrm{C}$, ground and kept in paper bags (Burton and David 1991; Fageria et al. 1991). After transferring soil samples to the laboratory, to reduce the activity of microorganisms, soil samples were kept at a temperature $1-2^{\circ} \mathrm{C}$, and soil extract was prepared (Estefan et al. 2013; Brady and Weil 1999). Also, some physiochemical properties of soil orchard samples were measured (Estefan et al. 2013; Bouyucos 1962), pH (Ryan et al. 1977; Ryan 2000), CEC (Sonmez et al.,2008; He et al. 2012), Organic matter (Walkley 1947; FAO 1974). The Olsen method was used to measure the content of soil and plant P (Olsen and Sommers 1982; Estefan et al. 2013). The range of changes in some physicochemical properties of the studied soils is shown in Table 1.

Table (1) Amplitude of changes in some Physicochemical properties of soil orchards.

\begin{tabular}{|llllll|}
\hline Texture & $\mathrm{pH}$ & $\mathrm{EC}_{\mathrm{e}} \mathrm{dSm}^{-1}$ & $\mathrm{CaCo}_{3} \%$ & $\mathrm{OM} \%$ & $\mathrm{CEC} \mathrm{Cmol}^{+} \mathrm{Kg}^{-1}$ \\
$\mathrm{SL}-\mathrm{CL}$ & $7.3-8.20$ & $655-1420$ & $34-40$ & $1.15-2.7$ & $15.8-35.7$ \\
\hline
\end{tabular}

\section{Data analysis}

First, a correlation matrix was performed between each soil characteristic ( $\mathrm{pH}, \mathrm{EC}, \mathrm{OM}, \mathrm{CEC})$, and $\mathrm{P}$ of plant organs (roots, stems, young and old leaves, fruit) with soil P (Table 2). Variables that had a significant correlation with soil P were selected and the correlation between those variables and soil phosphorus was investigated using multivariate regression analysis.

Table (2) Correlation coefficients of soil properties, soil available phosphorus and $\mathrm{P}$ in the plant organs in four sampling stages in all orchards. 


\begin{tabular}{|c|c|c|c|c|c|c|c|c|c|c|}
\hline & $\mathrm{SAP}^{1}$ & $\mathrm{OM}$ & $\mathrm{pH}$ & $\mathrm{EC}$ & CEC & root & stem & $\begin{array}{l}\text { Old } \\
\text { leaf }\end{array}$ & $\begin{array}{l}\text { Young } \\
\text { leaf }\end{array}$ & fruit \\
\hline SAP $^{1}$ & 1 & $0.083^{*}$ & $\begin{array}{l}-0.035 \\
n s\end{array}$ & $0.075^{*}$ & $\begin{array}{l}0.064 \\
\mathrm{~ns}\end{array}$ & $0.180 * \star$ & $-0.210^{\star \star}$ & $0.894^{\star \star}$ & $0.888^{\star \star}$ & $0.916^{\star \star}$ \\
\hline $\mathrm{OM}$ & $0.083^{*}$ & 1 & 0.091 & $0.074^{*}$ & $0.795^{\star \star}$ & $\begin{array}{l}0.054 \\
\mathrm{~ns}\end{array}$ & $\begin{array}{l}0.047 \\
\mathrm{~ns}\end{array}$ & $0.084^{\star}$ & $0.088^{*}$ & $0.076^{*}$ \\
\hline $\mathrm{pH}$ & $\begin{array}{l}-0.035 \\
n s\end{array}$ & $\begin{array}{l}0.091 \\
\mathrm{~ns}\end{array}$ & 1 & $0.081^{*}$ & $0.789 * \star$ & $\begin{array}{l}-0.010 \\
\mathrm{~ns}\end{array}$ & $\begin{array}{l}-0.052 \\
n s\end{array}$ & $\begin{array}{l}-0.012 \\
\mathrm{~ns}\end{array}$ & $\begin{array}{l}-0.041 \\
\mathrm{~ns}\end{array}$ & $\begin{array}{l}-0.061 \\
\mathrm{~ns}\end{array}$ \\
\hline EC & $0.075^{*}$ & $0.074^{*}$ & $0.081^{*}$ & 1 & $\begin{array}{l}0.031 \\
\mathrm{~ns}\end{array}$ & $\begin{array}{l}-0.036 \\
\mathrm{~ns}\end{array}$ & $\begin{array}{l}-0.013 \\
\mathrm{~ns}\end{array}$ & $\begin{array}{l}-0.011 \\
\mathrm{~ns}\end{array}$ & $-0.081^{*}$ & $-0.079^{*}$ \\
\hline CEC & $\begin{array}{l}0.064 \\
\mathrm{~ns}\end{array}$ & $0.795^{\star \star}$ & $0.789 * \star$ & $\begin{array}{l}0.031 \\
\mathrm{~ns}\end{array}$ & 1 & $\begin{array}{l}0.037 \\
\mathrm{~ns}\end{array}$ & $0.041^{*}$ & $0.013^{*}$ & $0.015^{\star}$ & $0.014^{*}$ \\
\hline root & $0.180 * \star$ & $\begin{array}{l}0.054 \\
\mathrm{~ns}\end{array}$ & $\begin{array}{l}-0.010 \\
n s\end{array}$ & $\begin{array}{l}-0.036 \\
n s\end{array}$ & $\begin{array}{l}0.037 \\
\mathrm{~ns}\end{array}$ & 1 & $-0.071^{*}$ & $0.198^{\star \star}$ & $0.206^{\star \star}$ & $0.219^{\star \star}$ \\
\hline stem & $-0.210^{\star \star}$ & $\begin{array}{l}0.047 \\
\mathrm{~ns}\end{array}$ & $\begin{array}{l}-0.052 \\
n s\end{array}$ & $\begin{array}{l}-0.013 \\
\mathrm{~ns}\end{array}$ & $\begin{array}{l}0.041 \\
\mathrm{~ns}\end{array}$ & $-0.071^{*}$ & 1 & $-0.233^{\star \star}$ & $-0.225^{\star \star}$ & $-0.213^{\star *}$ \\
\hline $\begin{array}{l}\text { Old } \\
\text { leaf }\end{array}$ & $0.894^{\star \star}$ & $0.084^{*}$ & $\begin{array}{l}-0.012 \\
\mathrm{~ns}\end{array}$ & $\begin{array}{l}-0.011 \\
\mathrm{~ns}\end{array}$ & $\begin{array}{l}0.013 \\
\mathrm{~ns}\end{array}$ & $0.198^{\star \star}$ & $-0.233^{\star \star}$ & 1 & $0.998^{\star \star}$ & $0.987^{\star \star}$ \\
\hline $\begin{array}{l}\text { Young } \\
\text { leaf }\end{array}$ & $0.888^{\star \star}$ & $0.088^{*}$ & $\begin{array}{l}-0.041 \\
\mathrm{~ns}\end{array}$ & $-0.081^{*}$ & $\begin{array}{l}0.015 \\
\mathrm{~ns}\end{array}$ & $0.206^{\star *}$ & $-0.225^{\star \star}$ & $0.998^{\star *}$ & 1 & $0.993^{\star \star}$ \\
\hline fruit & $0.916^{\star \star}$ & $0.076^{*}$ & $\begin{array}{l}-0.061 \\
\mathrm{~ns}\end{array}$ & $-0.079^{\star}$ & $\begin{array}{l}0.014 \\
\mathrm{~ns}\end{array}$ & $0.219^{\star \star}$ & $-0.213^{\star \star}$ & $0.987^{\star \star}$ & $0.993^{\star \star}$ & 1 \\
\hline
\end{tabular}

$\star^{\prime} * \star^{\prime n} n$ at the level of $5 \%$ and $1 \%$, respectively, have a significant difference, not significant. 1- Soil Available Phosphorus

From these calculations, two regression equations were obtained, one for high-yield orchards and the other for all orchards. Which according to these two regression equations, the quantitative amount of $P$ fertilizer required can be calculated (In the result, the calculation steps are shown with an example). Data analysis was performed by SPSS statistical software.

\section{Results And Discussion}

The correlation coefficients of soil properties, plant organs phosphorus with soil available phosphorus in all orchards and all four sampling showed a positive correlation between the soil phosphorus content and that in fruit $\left(0.916^{\star \star}\right)$, young leaves $\left(0.888^{\star *}\right)$, old leaves $\left(0.894^{\star *}\right)$, root $\left(0.180^{\star *}\right)$ and a negative correlation with stem $\left(0.210^{\star *}\right)$. Phosphorus of all plant organs showed a positive significant correlation with each other (Table 2).

\section{Regression model}

As indicated in Table 2, in all 468 samples, among soil properties and plant variables, only plant P of organs (old and young leaves, roots, stems and fruits) showed a significant correlation with soil P. Using the Enter method, a significant model was obtained in which $\left(\mathrm{R}^{2}\right.$ adj $\left.=0.962, \mathrm{~N}=468, \mathrm{P}<0.001\right)($ Table 3$)$.

Table (3) Analysis of variance between soil phosphorus and plant organs in four sampling stages in all orchards. 


\begin{tabular}{|lllllll|}
\hline Model & Sum of Squares & $\mathrm{df}$ & Mean Square & $\mathrm{F}$ & Sig. & Adjusted R Square \\
\hline Regression & 475078.188 & 5 & 95015.638 & 2.3303 & $0.000^{\mathrm{a}}$ & \\
\hline Residual & 18796.335 & 462 & 40.773 & & 0.962 \\
\hline Total & 493874.524 & 467 & & & & \\
\hline
\end{tabular}

a. Predictors: (Constant), P fruit, P stem, P root, P old Leaf, P young leaf

Table (4) Regression coefficients of soil phosphorus and plant organs in four sampling stages in all orchards.

\begin{tabular}{|llllll|}
\hline Model & \multicolumn{2}{l}{ Unstandardized Coefficients } & Standardized Coefficients & $\mathrm{t}$ & Sig. \\
\cline { 2 - 5 } & $\mathrm{B}$ & Std. Error & Beta & & \\
\hline (Constant) & -96.4673 & 23.65421 & & -3.140 & 0.009 \\
\hline P root & -0.007515 & 0.003513 & -0.020082 & -2.139 & 0.033 \\
\hline P stem & -0.001826 & 0.002473 & -0.006950 & -0.738 & 0.461 \\
\hline P old Leaf & 0.600533 & 0.018521 & 5.278000 & 32.425 & 0.000 \\
\hline P young Leaf & -0.759433 & 0.020242 & -8.144850 & -37.519 & 0.000
\end{tabular}

Although $\mathrm{P}$ of the stem had a significant correlation with the soil available $\mathrm{P}$ in the bivariate regression, but in the multivariate regression equation did not indicate a significant correlation (Tables 2 and 4). According to Table 4, the nonstandardized regression coefficient (B) in the model for estimating the soil available $P$ can be as follows:

$Y_{1}=-96.4673+0.600533 X_{1}+0.438697 X_{2}-0.759433 X_{3}-0.007515 X_{4}$

Where: $Y_{1}=$ soil available phosphorus, $X_{1}=$ phosphorous concentration in old leaves, $X_{2}=$ phosphorous concentration in fruits, $X_{3}=$ phosphorous concentration in young leaves, $X_{4}=$ phosphorous concentration in roots.

Considering that there is a significant correlation between $\mathrm{P}$ of plant organs, and there is a strong correlation between $\mathrm{P}$ of plant organs and also the highest correlation between $\mathrm{P}$ of fruit and $\mathrm{P}$ of other plant organs (Table 2). The mentioned multivariate regression equation can be simplified. For this purpose, on the right side of the equation, instead of the average $P$ of plant organs $\left(X_{i}\right)$, the ratio between the average $P$ of that organ and fruit $P\left(X_{1}\right)$ is set (Table 5). Therefore, the multivariate equation becomes a bivariate equation, and instead of measuring $P$ in all plant organs, only fruit $P$ is measured. As a result, above-mentioned model was more simplified while keeping its precision and effectiveness.

Table 5: Phosphorus amount in soil and plant organs in four sampling stages in all orchards.

\begin{tabular}{|lllllll|}
\hline & SAP* & Root & Stem & Old Leaf & Young Leaf & Fruit \\
\hline Average Concentration & 29.249 & 268.949 & 365.648 & 1088.77 & 1309.29 & 1058.02 \\
$\left(\mathrm{mg} \mathrm{Kg}^{-1}\right)$ & & & & & & \\
\hline
\end{tabular}

*Soil Available Phosphorus

$\frac{\text { root }}{\text { Fruit }}=0.25420 \quad \frac{\text { old Leaf }}{\text { Fruit }}=1.02906 \quad \frac{\text { Young Leaf }}{\text { Fruit }}=1.23749$ 
$Y_{1}=-96.4673+(0.600533)(1.02906) X_{1}+(0.438697) X_{1}-(0.754933)(1.23749) X_{1}-(0.007515)(0.25420) X_{1}$

With arithmetic summation of $\mathrm{X} 1$ in the both side of the model:

$Y_{1}=-96.4673+0.120549 X_{1}$

(Formula A)

$\mathrm{Y}_{1}=$ soil available phosphorus $\left(\mathrm{mg} \mathrm{Kg}^{-1}\right), \mathrm{X} 1=\mathrm{P}$ concentration in the fruits $\left(\mathrm{mg} \mathrm{Kg}^{-1}\right)$

\section{Regression model in high yield orchard}

In high-yield orchards $(n=216)$, as in other orchards, there was a significant correlation between soil $P$ and $P$ of plant organs, and the highest correlation was among fruit $\mathrm{P}$ with soil $\mathrm{P}$ and plant organs $\mathrm{P}$. Therefore, a multivariate regression equation was written between soil $P$ and plant organs $P$. Then, using the Enter method, a significant model was obtained $\left(R^{2}\right.$ adj $\left.=0.982,216=N, 0.001>P\right)($ Table 7).

Table (6) Analysis of variance between soil phosphorus and plant organs in four sampling stages in high yield orchards.

\begin{tabular}{|lllllll|}
\hline Model & Sum of Squares & df & Mean Square & $F$ & Sig. & Adjusted R Square \\
\hline Regression & 115726.700 & 4 & 28931.675 & 564.102 & $0.000^{\mathrm{a}}$ & \\
\hline Residual & 10821.763 & 211 & 51.288 & & 0.982 \\
\hline Total & 126548.463 & 215 & & & \\
\hline
\end{tabular}

a. Predictors: (Constant), P fruit, P stem, P root, P old Leaf, P young leaf

Table (7) Regression coefficients of soil phosphorus and plant organs in four sampling stages in high yield orchards.

\begin{tabular}{|llllll|}
\hline Model & \multicolumn{2}{l}{ Unstandardized Coefficients } & Standardized Coefficients & $\mathrm{t}$ & Sig. \\
\cline { 2 - 5 } & $\mathrm{B}$ & Std. Error & Beta & & \\
\hline (Constant) & -121.3799 & 26.065 & & -4.657 & 0.000 \\
\hline P old Leaf & 0.61211 & 0.030 & 5.123 & 20.691 & 0.000 \\
\hline P young Leaf & -0.78920 & 0.031 & -8.256 & -25.486 & 0.000 \\
P root & 0.005455 & 0.000537 & 0.09566 & 10.866 & 0.006 \\
\hline P fruit & 0.47110 & 0.015 & 3.966 & 30.736 & 0.000 \\
\hline
\end{tabular}

In this regression model, $\beta$ coefficient for fruits, root and old leaves $P$ variables were positive predictive, and for young leaves it was a negative predictive effect. Although, steam $\mathrm{P}$ had a significant correlation with soil available $\mathrm{P}$ in bivariate regression, but in the multivariate regression equation, there was no significant correlation with soil available $P$ (Table 6 and 7). Regarding unstandardized regression coefficients (B), The resulted model can be displayed as follows (Table 7).

$Y_{2}=-121.3799+0.005455 X_{1}+0.47110 X_{2}+0.61211 X X_{3}-0.78920 X_{4}$

Which: $Y_{2}=$ soil available phosphorus, $X_{1}=$ phosphorous concentration in root, $X_{2}=$ phosphorous concentration in fruits, $\mathrm{X}_{3}=$ phosphorous concentration in old leaves, $\mathrm{X}_{4}=$ phosphorous concentration in young leaves. 
Since P of plant organs had a significant correlation, and the highest correlation was between soil available P and fruit. The mentioned multivariate regression equation can be simplified. For this purpose, according to the table 8 , on the right side of the equation, instead of the average $P$ of plant organs $\left(X_{i}\right)$, the ratio between the average $P$ of that organ and fruit $\mathrm{P}\left(\mathrm{X}_{2}\right)$ is set. Therefore, the multivariate equation becomes a bivariate equation, and instead of measuring $\mathrm{P}$ in all plant organs, only fruit $\mathrm{P}$ is measured (Formula $\mathrm{B}$ ):

Table (8) Phosphorus amount in soil and plant organs in four sampling stages in high yield orchards.

\begin{tabular}{|c|c|c|c|c|c|c|}
\hline & SAP* & Root & Stem & Old Leaf & Young Leaf & Fruit \\
\hline 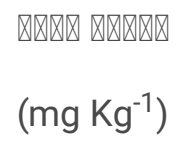 & 37.989 & 293.240 & 330.311 & 1310.940 & 1576.450 & 1273.899 \\
\hline
\end{tabular}

*soil available phosphorus

$$
\frac{\text { Root }}{\text { Fruit }}=0.23019 \quad \frac{\text { old leaf }}{\text { Fruit }}=1.02908 \quad \frac{\text { Young Leaf }}{\text { Fruit }}=1.2375
$$

$Y_{2}=-121.3799+(0.005455)(0.23019) X_{2}+(0.47110) X_{2}+(0.61211)(1.02908) X_{1}-(0.78920)(1.2375) X_{2}$

With arithmetic summation of $\mathrm{X} 1$ in the both side of the model:

\section{$Y_{2}=-121.3799+0.1256308 X_{2}$}

(Formula B)

$\mathrm{Y}_{2}=$ soil available phosphorus $\left(\mathrm{mg} \mathrm{Kg}^{-1}\right), \mathrm{X} 2=\mathrm{P}$ concentration in the fruits $\left(\mathrm{mg} \mathrm{Kg}^{-1}\right)$

The regression model obtained from four sampling stages of all orchards as well as high-yield orchards showed that there is a significant correlation between soil phosphorus and phosphorus of Washington Navel Orange organs. As mentioned, the result of this research is two formulas. Formula $A$, which shows the correlation between fruit $P\left(X_{1}\right)$ and soil $P\left(Y_{1}\right)$ in all orchards. The second formula $(B)$, shows the correlation between fruit $P\left(X_{2}\right)$ and soil phosphorus in high-yield orchards $\left(Y_{2}\right)$. If in Formula $(B)$ instead of $X_{2}$, the average $P$ concentration of the fruit is replaced from Table 8, the amount of soil $\mathrm{P}\left(\mathrm{Y}_{2}\right)$ will be obtained in high-yield orchards. Which is the norm of soil $\mathrm{P}$ in this region for orange plants. Also in which orchard probably has $P$ deficiency, in formula $(A)$ instead of $X_{1}$ is put the fruit $P$ of that orchard, and the soil $P$ of this orchard $\left(Y_{1}\right)$ will be calculated. Therefore, by Subtracting $Y_{1}$ from $Y_{2}$, the required $P$ is calculated quantitatively. The following example shows the application of this method and its formulas in fertilizer recommendation:

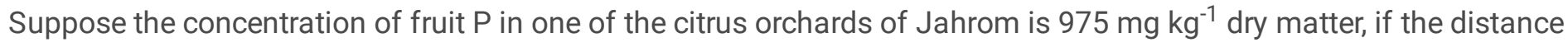
from one tree to another is 4 meters, the average root depth is $80-120 \mathrm{~cm}$, the average root expansion radius is 1.2 meters. To supply P, use triple superphosphate fertilizer ( $30 \% \mathrm{P})$ and the efficiency of fertilizer is $78 \%$. To reach the desired level of $P$, how much of this fertilizer is required in a ten-hectare orchard?

At First, put the amount of fruit phosphorus in formula (A) to obtain the concentration of soil available $\mathrm{P}(21.068 \mathrm{mg} \mathrm{kg}$ $\left.{ }^{1}\right)$. On the other hand, the average fruit $P$ in high yield orchards is $1273.899 \mathrm{mg} \mathrm{kg}^{-1}$ (table 8), by putting this amount in Formula $B$, the norm concentration of $P$ in the soils of this region for oranges will be $38.661 \mathrm{mg} \mathrm{kg}^{-1}$. Therefore, if subtract the amount of soil $\mathrm{P}$ from the norm concentration of the area, the amount of $\mathrm{P}$ required for that orchard will be $17.593 \mathrm{mg} \mathrm{kg}^{-1}$ soil. 
$Y_{2}-Y_{1}=>38.661-21.068=17.593 \mathrm{mg} \mathrm{P} \mathrm{kg}^{-1}$ soil Average $\mathrm{P}$ required per $\mathrm{kg}$ of soil

Average soil weight around the roots of each plant:

$M=B_{d} * h * A=>W=B d * h * \Pi r^{2}$

$M=1350 *(1.20-0.80) * 3.14 *(1.2)^{2}=2441.66 \mathrm{Kg}$

$M=$ soil weight $(\mathrm{Kg}), \mathrm{A}=$ Root spread area $\left(\mathrm{m}^{2}\right), \mathrm{h}=$ Average root depth $(\mathrm{m}), \mathrm{B}_{\mathrm{d}}=$ Bulk Density $\left(\mathrm{Kg} \mathrm{m}^{-3}\right), r=$ Radius of root expansion $(\mathrm{m})$

Since the area occupied by each tree is $16 \mathrm{~m}^{2}$ and the orchard area is 10 hectares $\left(10 * 10,000=1 * 10^{5} \mathrm{~m}^{2}\right)$, so the number of trees in this orchard is:

$N=1 * 10^{5}: 16=6250 \quad$ Number of orchard trees

Therefore, the amount of soil at the average depth of tree roots in this orchard is:

$W=M * N=>2441.66 * 6250=15260375 \mathrm{Kg}$

$\mathrm{W}=$ Average soil weight around the roots of all trees in this orchard.

As calculated, the amount of $P$ required for each kilogram of soil is $17.593 \mathrm{mg}$. It is also assumed that superphosphate fertilizer has $30 \% \mathrm{P}$ and its efficiency in soil is $78 \%$, therefore, $\mathrm{P}$ fertilizer require per each hectare is:

$F=1526037.5 *\left(17.593 * 10^{-6}\right) *(100: 30) *(100: 78)=118.73 \mathrm{Kg} \mathrm{ha}^{-1}$

$\mathrm{F}=$ Phosphorus fertilizer require $\left(\mathrm{Kg} \mathrm{ha}^{-1}\right)$

\section{Discussion}

As shown in all 468 samples, there is a significant correlation between soil $\mathrm{P}$ and $\mathrm{P}$ of plant organs, and the highest correlation is between soil phosphorus and fruit $\mathrm{P}\left(0.916^{\star *}\right)$. On the other hand, $\mathrm{P}$ of all plant organs has a significant positive correlation with each other and the highest level of correlation is between the $P$ of each organ with the $P$ of the fruit. This may be due to the role of $P$ in the growth and development of plant reproductive organs (Lihong Wei and Qiuxi Zhai 2010; Zhu et al. 2014; Kiminori Yoshikawa et al. 2015; Zhang Zhihong et al. 2017; Santos et al. 2018; Wei Feng et al. 2020). According to the results, it seems that fruit $P$ is a more suitable indicator for examining the status of $P$ in this plant than soil $\mathrm{P}$ or $\mathrm{P}$ of other plant organs. Therefore, it seems more logical that fertilizer recommendation should be based on the intensity of the correlation between the concentration of element $(P)$ in the soil and plant organs, not just the concentration of element $(P)$ in the soil or a specific plant organ such as leaves (Slavich and Petterson 1993; Shaw 1994; Zhang et al. 2005; Sonmez et al. 2008; Ejraei et al. 2018, 2019). While almost all fertilizer recommendation methods are qualitative and are not able to determine quantitatively of fertilizer required. In some of the most popular methods, such as DRIS, the ratio between the elements is examined instead of the concentration of the elements (Beufils 1973; Hundal et al. 2005; Nayak et al. 2011; Raghupathi and Srinivas 2014; Gott et al. 2017). In CNC and CNR methods, the status of nutrients in the soil or plant is expressed in terms of Low, High and Medium (Venkatesh et al. 2014; Beranger et al. 2015). Also in DOP method, the concentration of elements in the plant is shown with Positive and Negative terms (Montañes et al. 1993; Lucena 1997; Sanz 1999; Ignacio et al. 2016). And in none of them the amount of element required is not calculated quantities. The method used in this study is called Integrated Plant and Soil System (IPSS). In this system contrary to the methods mentioned, the recommended fertilizer is based on the correlation 
between each divisive element in the soil and plant organs. This method (IPSS) is quantitative and fertilizer required for each element is precisely measurable. On the other hand, in most fertilizer recommendation methods, the leaf is an indicator for determining the nutritional status of all the elements and the basis for their fertilizer recommendation. While, the chemical properties and the role of each element in each of the plant organs is different from other elements. Therefore, it is more logical that fertilizer recommend is based on the relationship between the concentration of the element in the soil and that plant organ, which has the highest correlation with the concentration of that element in the soil, not merely based on the concentration of phosphorus (element) in the soil or plant leaves. The method used in this study is called Integrated Plant and Soil System (IPSS). In this system contrary to the methods mentioned, fertilizer recommendation is based on the correlation between the element in the soil and plant organs. This method (IPSS) is quantitative and fertilizer required for each element is precisely measurable. On the other hand, in most fertilizer recommendation methods, the leaf is an indicator for determining the nutritional status of all the elements and the basis for their fertilizer recommendation. While, the chemical properties and the role of each element in each of the plant organs is different from other elements. Also in recent years, many agricultural researchers have proven the correlation between soil nutrients and plant organs (Sharpley et al. 1989; Samira et al. 2003; Kiminori Yoshikawa et al. 2015). Another important point to note is that the behavior of elements such as $\mathrm{P}$ in the soil is very complex and therefore there are different methods with various extractors to measure $\mathrm{P}$ in the soil. But the amount of phosphorus measured in a soil is not the same in any of them (Bray and Kurtz 1945; Lindsay 1979; Mehlich 1984; Soltanpour and Schwab 1977). In IPSS, the amount of soil P is accurately measured only once to determine the Norm concentration of phosphorus in pilot studies. By measuring plant $\mathrm{P}$ and correlation between soil $\mathrm{P}$ and plant phosphorus can determine the amount of $\mathrm{P}$ fertilizer required. Which is another advantage over conventional methods.

\section{Abbreviations}

Integrated Plant and Soil System (IPSS), Phosphorus (P), Washington Navel Orange (WNO).

\section{References}

1. Beranger G, Noura Z, Denis P, Cynthia G, Merja H, Perttu V, Zhengyi H, Jia L, Jean L, Judith N (2015) A Model of Critical Phosphorus Concentration in the Shoot Biomass of Wheat. Agron., J., 107(3): 963-970.

2. Beufils ER (1973) Diagnosis and recommendation integrated system (DRIS). Soil Sci. Bull. No. 1, Univ. Natal, South Africa.

3. Beverly R, Stark B, Oyala JC, Embleton TW (1984) Nutrient diagnosis of Valencia orange by DRIS. J. Amer. Hort. Sci., 109: 649-654.

4. Bouyoucos GJ (1962) Hydrometer method improved for making particle-size analysis of soils. Agron., J., 53: 464 465.

5. Bray RH, Kurtz LT (1945) Determination of total, organic, and available forms of phosphorus in soils. Soil Sci. 59: 39-45.

6. Brady NC, Weil RR (1999) The nature and properties of soils. $12^{\text {th }}$ ed., Prentice Hall, Upper Saddle River, New Jersey, USA.

7. Bujnovský R, Malík P. Švasta J (2016) Evaluation of the risk of diffuse pollution of groundwater by nitrogen substances from agricultural land use as background for allocation of effective measures. Ekologia, 35(1): 66-77.

8. Burton NL, David SA (1991) Angora goats in Alabama woodlands. In: S. G. Solaiman, and W.A. Hill, eds. Using goats to manage forest vegetation: A regional inquiry: Workshop proceedings; [Date of conference unknown]; [Location of conference unknown]. Tuskegee, AL: Tuskegee Agricultural Experiment tation: 78-83.

Page 10/14 
9. Campbell CR, Plank CO (1998) Preparation of plant tissue for laboratory analysis. P: 37-52. In: Y. P. Kalra) eds.), Handbook of Methods for Plant Analysis, Soil and Plant Analysis Council, Inc.

10. Carter MR (1993) Soil sampling and methods of analysis. Lewis publishers, Boca Raton, Florida, USA.

11. Cate RB, Nelson LA (1965) A rapid method for correlation of soil test analyses with plant response data. North Carolina Agric. Exp. Stn. International Soil Testing Series, Tech. Bull. No.1.

12. Ceulemans T, Hulsmans E, Berwaers S, Van Acker K, Honnay O (2017) The role of above-ground competition and nitrogen vs. phosphorus enrichment in seedling survival of common European plant species of semi-natural grasslands, PLOS ONE, 12:3, e0174380. DOI: 10.1371/journal.pone.0174380.

13. Chen X, Zhang F, Römheld V, Horlacher D, Schulz R, Böning-Zilkens M, Wang P, Claupein W (2006) Synchronizing N supply from soil and fertilizer and $\mathrm{N}$ demand of winter wheat by an improved Nmin method. Nutr, Cycl. Agroecosys. 74: $91-98$.

14. Ciesielska J, Malusa E, Bourlot G (2002) Grape leaf diagnosis in the Piedmont Region, Acta Hort., 594: $387-392$.

15. Dow A, Roberts S (1982) "proposal: Critical Nutrient Ranges for crop diagnosis", Argon J., 74:40.

16. Ejraei A, Mohammadi Ghehsareh A, Hodaji M, Besalatpor AA (2018) Determine a Regression Model between Phosphorus of Soil Saturation Extract and Various Organs of Washington Navel Orange for Recommendation of Phosphorus Fertilizer. Int J Hort Sci Tech. 5(2): 175-184. http://dx.doi.org/10.22059/ijhst.2018.254225.227.

17. Ejraei A, Mohammadi Ghehsareh A, Hodaji M, Besalatpor AA (2019) Regression-based phosphorus recommendation model for Washington Navel. J Plant Nutr, 42:18. DOI: 10.1080/01904167.2019.1643364.

18. Estefan G, Sommer R, Ryan J (2013) Method of soil, plant and water analysis a manual for the West Asia and North Africa ragion. ICARDA (International Center for Agricultural Research in the Dry Areas), thirth edition, Box114/5055, Beirut, Lebanon, ICARDA@cgiar.org www.icarda.org.

19. Fageria NK, Baligar VC, Jones CA (1991) Growth and mineral nutrition of field crop, Marcel Dekker, New York.

20. FAO (1974) The Euphrates Pilot Irrigation Project, Methods of soil analysis, Gadeb Soil Laboratory (A laboratory manual), Food and Agriculture Organization, Rome, Italy.

21. Ferrise R, Triossi A, Stratonovitch P, Bindi M, Martre,P (2010) Sowing date and nitrogen fertilization effects on dry matter and nitrogen dynamics for durum wheat: An experimental and simulation study. Field Crops Res. 117: 245257.

22. Ford H, Roberts A, Jones $L$ (2016) Nitrogen and phosphorus co-limitation and grazing moderate nitrogen impacts on plant growth and nutrient cycling in sand dune grassland. Sci Total Environ. 542: 203-209. DOI: 10.1016/j.scitotenv.2015.10.089.

23. García-Escudero E, Romero I, Benito A, Dominguez N, Martín I (2013) Reference levels for leaf nutrient diagnosis of cv 'Tempranillo' grapevine (Vitis vinifera L.) in the Rioja Appellation. Commun Soil Sci. Plant Anal. 44: 645-654.

24. Gott RM, Aquino LA, Clemente JM, Santos LPD, Carvalho AM, Xavier FO (2017) Foliar Diagnosis Indexes for Corn by the Methods Diagnosis and ecommendation Integrated System (DRIS) and Nutritional Composition (CND). Commun Soil Sci Plant Anal. 48(1): 11-19.

25. Halitligil M, Akin A, Ibeyi A (2002) Nitrogen balance of nitrogen-15 applied as ammonium sulphate to irrigated potatoes in sandy textured soils. Biol. Fertil. Soils. 35: 369-378.

26. Halajnia A, Haghnia GH, Fotovat A, Khorasani R (2009) Phosphorus fractions in calcareous soils amended with $P$ fertilizer and cattle manure. Geoderma 150: 209-213.

27. He Y, DeSutter T, Prunty L, Hopkins D, Jia X, Wysocki D (2012) Evaluation of 1:5 soil to water extract electrical conductivity methods. Geoderma, 185-186, 12-17. Doi: 10.1016/j.geoderma.2012.03.022. 
28. Hundal HS, Dhanwinder S, Brar JS (2005) Diagnosis and Recommendation Integrated System for Monitoring Nutrient Status of Mango Trees in Submountainous Area of Punjab, India. Commun Soil Sci. Plant Anal. 36: 20852099.

29. Ignacio M, Izaskun R, Natalia D, Ana B, Enrique G (2016) Comparison of DOP and DRIS Methods for Leaf Nutritional Diagnosis of Vitis Vinifera L., Cv. 'Tempranillo'. Commun Soil Sci. Plant Anal.

Doi.org/10.1080/00103624.2015.1123720.

30. Jones BJ (1998) Field sampling procedures for conducting plant analysis, P. 25-35. In: Y. P. Kalra (eds.), Handbook of Methods for Plant Analysis, Soil and Plant Analysis Council, Inc

31. Ju XT, Xing GX, Chen XP, Zhang SL, Zhang LJ, Liu XJ, Cui ZL, Yin B, Christie P, Zhu ZL, Zhang FS (2009) Reducing environmental risk by improving $\mathrm{N}$ management in intensive Chinese agricultural systems. Proc Natl Acad Sci. 106: 3041-3046.

32. Kiminori Y, Akihiro N, Akiko B, Shinnosuke K (2015) The influence of reduced rate of application of phosphorus and potassium fertilizer on fruit quality and soil in Satsuma Mandarin Orchard. Acta Hortic.1065. DOI:

10.17660/ActaHortic.2015.1065.230.

33. Le C, Zha Y, Li Y, Sun D, Lu H, Yin B (2010) Eutrophication of lake waters in China: cost, causes, and control, Environ Manage. 45: 662-668.

34. Li D, Li X, Han Q, Zhou Y, Dong J, Duan Z (2020) Phosphorus application improved the yield of citrus plants grown for three years in an acid soil in the Three Gorges Reservoir Area. Sci Hortic. 273, 109596. DOI: 10.1016/j.scienta.2020.109596.

35. Liang XQ, Xu L, Li H, He MM, Qian YC, Liu J, Nie ZY, Ye YS, Chen YX (2011) Influence of N fertilization rates, rainfall, and temperature on nitrate leaching from a rainfed winter wheat field in Taihu watershed. Phys. Chem. Earth 36: 395-400.

36. Lihong W, Qiuxi Z (2010) The dynamics and correlation between nitrogen, phosphorus, potassium and calcium in a hazelnut fruit during its development, Front Agric China. 4(3): 352-357. DOI: 10.1007/s11703-010-1010-1.

37. Lindsay WL (1979) Chemical Equilibria in Soils; John Wiley \& Sons: New York. Lu, Xiao Hui; Wang, Yang, 2013, Study on the Effects of Nitrogen Pollution to the Soil and Groundwater, Applied Mechanics and Materials, 437: 1019-1022.

38. Lu XH, Wang Yang (2013) Study on the Effects of Nitrogen Pollution to the Soil and Groundwater. Appl Mech Mater. 437: 1019-1022.

39. Lucena JJ (1997) Methods of diagnosis of mineral nutrition of plants. A critical review, Acta Hort. 448: 179-192.

40. Ma YB, Li JM, Li XY, Tang X, Liang YC, Huang SM, Wang B, Liu H, Yang XY (2009) Phosphorus accumulation and depletion in soils in wheat-maize cropping systems: modeling and validation. Field Crops Res. 110: 207-212.

41. Malhi SS, Lemke R (2007) Tillage, crop residue and N fertilizer effects on crop yield, nutrient uptake, soil quality and nitrous oxide gas emissions in a second 4-yr rotation cycle. Soil Till. Res. 96: 269-283.

42. Mehlich A (1984) Mehlich 3 soil test extractant: a modification of Mehlich 2 extractant. Commun Soil Sci Plant Anal. 15: 1409-1416.

43. Montañés L, Heras L, Abadía J, Sanz M (1993) Plant analysis interpretation based on a new index: deviation from optimum percentage (DOP). J Plant Nutr. 16: 1289-1308.

44. Mourao Filho FAA (2004) DRIS: concepts and applications on nutritional diagnosis in fruit crops. Sci Agr. 61: 550560.

45. Nayak AK, Sharma DK, Singh CS, Mishra VK, Singh G, Swarup A (2011) Diagnosis and recommendation integrated system approach for nitrogen, phosphorus, Potassium, and Zinc foliar diagnostic norms for AONLA in central IndoGangetic plants. J Plant Nutr. 34(4): 547-556.

Page $12 / 14$ 
46. Olsen SR, Sommers LE (1982) Phosphorus, p. 403 - 430. In A. L. Page (ed.), Methods of soil analysis, Agron. No. 9 , Part 2: Chemical and microbiological properties, 2nd ed., Am. Soc. Agron., Madison, WI, USA.

47. Pantigoso HA, Yuan J, He Y, Guo Q, Vollmer C, Vivanco JM (2020) Role of root exudates on assimilation of phosphorus in young and old Arabidopsis thaliana plants. PLOS ONE, 15(6): e0234216. doi: 10.1371/journal.pone.0234216.

48. Raghupathi HB, Srinivas S (2014) Spatial Variability Studies in Banana for Identification of Nutrient Imbalance Using Diagnosis and Recommendation Integrated System. Commun Soil Sci Plant Anal. 45(12): 1667-1686.

49. Robinson JB (2005) Critical plant tissue values and application of nutritional standards for practical use in vineyards, Proc Soil Mineral Environment and Vine Nutrition Symposium, San Diego, CA (USA), June 29- 30, 2004. (Christensen LP, Smart, DR, eds.). ASEV, Davis, CA (USA). pp: 61-68.

50. Ryan J, Estefan G, Rashid A (1977) Soil and Plant Analysis Laboratory Manual.

51. Ryan J (2000) Soil and plant analysis in the Mediterranean region: Limitations and potential. Commun Soil Sci Plant Anal. 31(11 - 14): 2147 - 2154.

52. Sajjadi A (1992) Diagnosis and Recommendation Integrated System-DRIS.Technical issue No. 847. Iran J Soil Water Res. Tehran, Iran, 94p. (In Persian).

53. Sanchez CA (2007) Phosphorus. In: Barker AV, Pilbeam DJ (eds), Handbook of Plant Nutrition. CRC Press, Boca Raton, FL, pp 51-90.

54. Samira H, Daroub AG, Joe TR, Dennis KF, Ryan J (2003) Development of a soil-plant phosphorus simulation model for calcareous and weathered tropical soils. Agric Syst. 76(3): 1157-1181. DOI: 10.1016/s0308-521x (02)00082-3.

55. Sonmez S, Buyuktas D, Okturen F, Citak S (2008) Assessment of different soil to water ratios $(1: 1,1: 2.5,1: 5)$ in soil salinity studies, Geoderma. 144 (1-2): 361-369.

56. Santos GPereira, Cavalcante LF, Nascimento JAM, Lima Neto AJ, Medeiros SAS, Cavalcante ÍHL (2018) Nutritional status of yellow passion fruit fertilized with phosphorus sources and doses. J. Soil Sci. Plant Nutr. issue ahead. DOI: 10.4067/s0718-95162018005001204.

57. Sanz M (1999) Evaluation of interpretation of DRIS system during growing season of the peach tree: Comparison with DOP method. Commun Soil Sci Plant Anal. 30: 1025-1036.

58. Sharpley AN, Singh U, Uehara G, Kimble J (1989) Modeling Soil and Plant Phosphorus Dynamics in Calcareous and Highly Weathered Soils. SOIL SCI SOC AM J. 53(1): 153-159. DOI:10.2136/sssaj1989.03615995005300010029x.

59. Shaw R (1994) Estimation of the electrical conductivity of saturation extracts from the electrical conductivity of $1: 5$ soil: water suspensions and various soil properties, Project Report Series Q094025, Dept. of Primary Industries, Queensland, Australia.

60. Slavich PG, Petterson GH (1993) Estimating the electrical-conductivity of saturated paste extracts from 1-5 soil, water suspensions and texture, AUST J SOIL RES. 31 (1): 73-81.

61. Soltanpour PN, Schwab AP (1977) A new soil test for simultaneous extraction of macro-, and micro-nutrients in alkaline soils. Commun. Soil Sci. Plant Anal. 8:195-207.

62. Su H, Kang W, Xu Y, Wang J (2017) Assessing Groundwater Quality and Health Risks of Nitrogen Pollution in the Shenfu Mining Area of Shaanxi Province, Northwest China. Exposure and Health, 10(2): 77-97.

Doi:10.1007/s12403-017-0247-9.

63. Sumner ME, (1977) Use of the DRIS system in foliar diagnosis of crops at high yield levels. Commun.Soil Sci Plant Anal. 8: 251-268.

64. Valkama E, Uusitalo R, Ylivainio K, Virkajrvi P, Turtola E (2009) Phosphorus fertilization: a meta-analysis of 80 years of research in Finland. Agric Ecosyst Environ. 130: 75-85.

Page $13 / 14$ 
65. Vance CP, Uhde-Stone C, Allan DL (2003) Phosphorus acquisition and use: critical adaptations by plants for securing a nonrenewable resource. New Phytol. 157: 423-447.

66. Vasileios A, Vasiliki A, Konstantinos T, Spyridon K (2013) Development of a Simplified Model for Nitrogen Fertilizer Recommendation for Maize, Wheat, and Sunflower in Northern Greece. Commun Soil Sci Plant Anal. 44:62-79.

67. Venkatesh MS, Hazra KK, Ghosh PK (2014) Determination of critical tissue phosphorus concentration in MUNGBEAN and URDBEAN for plant diagnosis. J Plant Nutr. 37(12): 2017-2025.

68. Walkley A (1947) A critical examination of a rapid method for determining organic carbon in soils: Effect of variations in digestion conditions and of organic soil constituents. Soil Sci. 63: $251-263$.

69. Wei F; Shi Z, Wan R, Li Y, Wang Y, An W et al (2020) Impact of phosphorus fertilizer level on the yield and metabolome of goji fruit. Sci. Rep.10:1. DOI: 10.1038/s41598-020-71492-y.

70. Xiao L, Jiang H, Shen C, Li K, Hu L (2019) Role of different plants on nitrogen and phosphorus removal at low temperature in lab-scale constructed wetlands. E3S Web of Conferences, 118, 01023. doi:10.1051/e3sconf/201911801023.

71. Xu X, He P, Pampolino MF, Johnston AM, Qiu S, Zhao S, Chuan L, Zhou W (2014) Estimating a new approach of fertilizer recommendation across small holder farms in China. Field Crops Res. 163: 10-17.

72. Zambrosi FCB, Mattos D, Quaggio JA, Cantarella H, Boaretto RM (2013) Phosphorus Uptake by Young Citrus Trees in Low-P Soil Depends on Rootstock Varieties and Nutrient Management. Commun Soil Sci Plant Anal. 44(14): 2107-2117. doi:10.1080/00103624.2013.799680.

73. Zhang YM, Hu CS, Zhang JB, Chen DL, Li XX (2005) Nitrate leaching in an irrigated wheat-maize rotation field in the North China Plain. Pedosphere 15:196-203.

74. Zhang Z, Cao F, Li H, Li X, Dai H, (2017) Correlation between phosphorus content and fruit quality in strawberries. Acta Hortic.1156. DOI: 10.17660/ActaHortic.2017.1156.96.

75. Zheng XH, Han SH, Huang Y, Wang YS, Wang MX (2004) Re-quantifying the emission factors based on field measurements and estimating the direct $\mathrm{N}_{2} \mathrm{O}$ emission from Chinese croplands. Global Biogeochem. Cycles. 18: 119.

76. Zhu B, Lu YQ, Zhang XZ, Wang Y, Liu HP, Han ZH (2014) Reduced late-season leaf potassium and phosphorus levels influence decreases in sugar contents of bagged apple fruit. Acta Physiol. Plant. 6:6. DOI: 10.1007/s11738014-1533-9. 